\title{
PROBLEMATIKA GURU DALAM MENGGUNAKAN MEDIA PEMBELAJARAN PADA KURIKULUM 2013 (STUDI KASUS DI SD NEGERI 1 TAMAN AYU)
}

\author{
Titin Nur Adianti ${ }^{1)}$, Moh. Irawan Zain ${ }^{2)}$, Lalu Hamdian Affandi ${ }^{3)}$ \\ 1), 2), 3) Program Studi PGSD, FKIP - Universitas Mataram \\ *Corresponding Author: titinnuradianti@gmail.com
}

\begin{abstract}
ARTICLE INFO
ABSTRACT

Article history

Received : October $8^{\text {st }}, 2021$

Revised : November $28^{\mathrm{st}}, 2021$

Accepted : Desember $8^{\text {st }}, 2021$

Keywords:

Teacher Problems, Learning Media, Curriculum 2013

The purpose of this study is to describe the problem of teachers in using learning media in the 2013 curriculum at SDN 1 Taman Ayu, Gerung District. The research approach used is qualitative research with the type of case study research. Data collection techniques using interviews, observation and documentation. Data analysis used Milles and Huberman model data analysis. The results of the study indicate that the difficulties experienced by teachers include; 1) the difficulty of the teacher in choosing the media to be used. 2) Difficulties of teachers in using learning media 3) Difficulties of teachers in evaluating the use of learning media. the way the teacher overcomes these obstacles is to carry out reflection activities to restore student learning concentration, use student books, provide special guidance for students who have difficulties in understanding learning materials, evaluate media at other times. It can be concluded that teachers at SDN 1 Taman Ayu, Gerung Sub-district experienced problems in using learning media in the 2013 curriculum.
\end{abstract}

\begin{abstract}
Abstrak Tujuan penelitian ini yaitu mendeskripsikan gambaran problematika guru dalam menggunakan media pembelajaran pada kurikulum 2013 di SDN 1 Taman Ayu Kecamatan Gerung. Pendekatan penelitian yang digunakan adalah penelitian kualitatif dengan jenis penelitian studi kasus. Teknik Pengumpulan data menggunakan wawancara, observasi dan dokumentasi. Analisis data menggunakan analisis data Model Milles dan Huberman. Hasil penelitian menunjukkan bahwa kesulitan yang dialami oleh guru diantaranya; 1) kesulitan guru dalam memilih media yang akan digunakan. 2) Kesulitan guru dalam menggunakan media pembelajaran 3) Kesulitan guru dalam melakukan evaluasi penggunaan media pembelajaran. cara guru mengatasi kendala tersebut yaitu melakukan kegiatan refleksi untuk mengemablikan konsentrasi belajar siswa, menggunakan buku siswa, memberikan bimbingan khusus bagi siswa yang memiliki kesulitan dalam memahami materi pembelajaran, melakukan evaluasi media dilain waktu. Dapat disimpulkan bahwa guru di SDN 1 Taman Ayu Kecamatan Gerung mengalami problematika dalam menggunakan media pembelajaran pada kurikulum 2013.
\end{abstract}

\section{A. PENDAHULUAN}

Media pembelajaran merupakan salah satu komponen pembelajaran yang mempunyai peran penting dalam kegiatan belajar mengajar. Ranah pendidikan yang 
berbasis kurikulum 2013 para guru dituntut untuk menggunakan media yang di tentukan oleh kurikulum itu sendiri. Pelaksanaan pembelajaran tematik pada kurikulum 2013 diharapkan dapat memacu kreatifitas guru dalam menciptakan inovasi pembelajaran. Sadiman (2014) inovasi pembelajaran dapat diwujudkan melalui pengembangan strategi, pendekatan, model dan media pembelajaran sehingga guru harus mampu mengembangkan kemampuan dan meningkatkan kreatifitas yang dimiliki. (Arsyad., 2014; Sadiman et. al, 2014; Kustandi et. al, 2011). Media pembelajaran adalah alat yang digunakan untuk memperjelas makna pesan yang disampaikan, sehingga merangsang pikiran, perasaan, perhatian dan minat siswa dalam belajar sehingga dapat mencapai tujuan pembelajaran dengan lebih baik dan sempurna.

Selain itu, dalam memilih dan menggunakan media, juga ada beberapa kriteria yang harus diperhatikan oleh guru. (Arsyad, 2014; Sudjana et. al. 2015). Dalam menggunakan media, media harus sesuai dengan tujuan pembelajaran, haruslah mendukung materi pembelajaran, mudah diperoleh, sesuai dengan keterampilan guru, ketersediaan waktu, dan sesuai dengan taraf berpikir siswa. Untuk mewujudkan hal tersebut, faktor penentu keberhasilan peserta didik dalam pendidikan salah satunya adalah kemampuan guru menggunakan media pembelajaran.

Pemanfaatan media seharusnya merupakan bagian yang harus mendapat fasilitator dalam kegiatan pembelajaran. Oleh karena itu guru perlu mempelajari bagaimana menetapkan media pembelajaran agar dapat mengefektifkan pencapaian tujuan pembelajaran dalam proses mengajar. Pada kenyataanya media pembelajaran masih sering terabaikan dengan berbagai alasan, antara lain: terbatasnya waktu untuk membuat media persiapan mengajar, sulit mencari media yang tepat, tidak tersedianya biaya dan lain-lain. Hal ini sebenarnya tidak perlu terjadi jika setiap guru telah mempunyai pengetahuan dan keterampilan mengenai media pembelajaran.

Berdasarkan wawancara awal yang dilakukan pada SD Negeri 1 Taman Ayu pada bulan Juni 2020, hambatan yang menjadi faktor utama problematika guru dalam menggunakan media pembelajaran pada kurikulum 2013 yaitu guru masih kesulitan dalam menyesuaikan media dengan materi pembelajaran, ketersediaan media kurikulum 2013 belum ada.

Hal tersebut senada dengan hasil penelitian yang dilakukan oleh (Lutfi et.al., 2013; Untari, 2017; Wulantari, 2021). Adapun problematika yang di hadapi guru dalam menggunakan media antara lain: kurangnya waktu untuk membuat media pembelajaran, kurangnya keterampilan/kemampuan dalam membuat media, kendala biaya, dan belum tersedia media pembelajaran pada kurikulum 2013, Hal ini di sebabkan oleh kemampuan guru yang beragam.

Penelitian sebelumnya banyak sekali mengkaji tentang problematika guru dalam menggunakan media pembelajaran secara spesifik yaitu berbasis TIK ataupun problematika dalam penggunaan media pembelajaran pada mata pelajaran tertentu. Oleh karena itu penelitian ingin memfokuskan penelitian ini mengkaji kearah problematika guru dalam menggunakan media pembelajaran secara umum pada pembelajaran tematik di sekolah dasar, dengan mengangkat judul "Analisis Problematika Guru dalam Menggunakan Media Pembelajaran Kurikulum 2013 di SD Negeri 1 Taman Ayu”. 


\section{B. METODE PENELITIAN}

Jadi metode penelitian yang digunakan peneliti adalah metode kualitatif dengan menggunakan pendekatan deskriptif yang digunakan untuk mendeskripsikan problematika guru dalam menggunakan media pembelajaran kurikulum 2013, berdasarkan data dan fakta yang terjadi di lapangan. Sukardi (2011) mengatakan bahwa "penelitian deskriptif merupakan penelitian yang berusaha menggambarkan secara jelas dan sistematis kegiatan penelitian yang dilakukan pada objek tertentu. Sedangkan metode kualitatif menurut Bogdan dan Taylor (Moleong, 2000) metodologi kualitatif merupakan prosedur penelitian yang menghasilkan data deskriptif berupa kata-kata tertulis atau lisan dari orang-orang tertentu dan perilaku yang diamati. Desain penelitian ini adalah studi kasus tunggal merupakan "jenis penelitian studi kasus yang memungkinkan peneliti untuk melakukan eksplorasi mendalam dan spesifik tentang kejadian tertentu atau beberapa peristiwa dari sebuah fenomena" (Tohirin, 2012).

Teknik pengumpulan data dilakukan melalui wawancara mendalam dan dokumentasi. Analisis data pada penelitian ini menggunakan pendapat Miles and Huberman (Moleong, 2000) yang meliputi tiga hal yaitu reduksi data, penyajian data dan penarikan kesimpulan. Reduksi data merupakan proses menelaah terhadap data-data yang dihasilkan dikategorikan sesuai dengan aspek atau fokus penelitian. Penyajian data sebagai upaya untuk memaparkan data penelitian dalam bentuk tulisan yang bersifat naratif supaya lebih jelas dan mudah dipahami. Penarikan kesimpulan merupakan ringkasan dari sajian data berupa temuan-temuan dalam penelitian, yang disajikan dalam kalimat yang singkat, padat dan bermakna. Narasumber dalam penelitian ini adalah guru di SD 1 Taman Ayu dari guru kela 1-6.

Pada dasarnya bagian ini menjelaskan bagaimana penelitian itu dilakukan. Materi pokok bagian ini adalah: (1) pendekatan/ jenis penelitian; (2) sumber data; (3) teknik dan instrumen pengumpulan data; dan (4) teknik analisis data. Untuk penelitian yang menggunakan alat dan bahan, perlu dituliskan spesifikasi alat dan bahannya. Spesifikasi alat menggambarkan kecanggihan alat yang digunakan sedangkan spesifikasi bahan menggambarkan macam bahan yang digunakan.

Untuk penelitian kualitatif seperti penelitian tindakan kelas, etnografi, fenomenologi, studi kasus, dan lain-lain, perlu ditambahkan peneliti sebagai instrumen (human instrument), subjek penelitian, informan yang ikut membantu beserta cara-cara menggali data-data penelitian, lokasi dan lama penelitian serta uraian mengenai pengecekan keabsahan hasil penelitian.

\section{HASIL DAN PEMBAHASAN}

Berdasarkan hasil wawancara dan dokumentasi selama penelitian yang di laksanakan oleh peneliti dari tanggal 29-30 Desember 2020, berikut disajikan paparan data hasil penelitian. Paparan data ini sesuai dengan tujuan peneliti yakni untuk mendeskripsikan problematika guru dalam menggunakan media pembelajaran kurikulum 2013, faktor penyebab dari problematika yang dialami dan bagaimana solusi guru untuk mengatasi problematika yang dihadapi dalam menggunakan media pembelajaran kurikulum 2013. Berikut merupakan paparan hasil penelitian. 


\section{Kendala Dalam Perencanaan Media Pembembelajaran}

Kendala pertama guru masih kesulitan dalam melakukan perencanaan penggunaan media pembelajaran. Dalam membuat perencanaan media guru mengalami kesulitan dalam menentukan media pada pembelajaran tematik ada beberapa materi pembelajaran yang dirasa guru cukup sulit untuk ditentukan mediannya jadi ketika mengalami kendala tersebut guru lebih sering mengadalkan buku siswa sebagai sumber belajar.

Setiap media pembelajaran memiliki karakteristik tertentu, baik dilihat dari keunggulannya, cara pembuatnnya maupun cara penggunaannya. Dalam memilih dan menggunakan media, ada banyak kriteria dan prinsif-prinsif yang harus dipahami oleh guru. Sebagaimana diungkapkan oleh Sumantri (1999:181) bahwa ada lima prinsif yang harus diperhatikan dalam memilih media pembelajaran, yakni: 1) sesuai dengan tujuan dan bahan pengajaran; 2) sesuai dengan kemampuan guru; 3) sesuai dengan tingkat perkembangan peserta didik; 4) sesuai dengan situasi dan kondisi (tempat dan waktu); dan 5) memahami karakteristik media yang digunakan. Selain itu, dalam memilih dan menggunakan media, juga ada beberapa kriteria yang harus diperhatikan oleh guru. Sudjana dan Rivai (2015) mengidentifikasi enam kriteria berikut: 1) media yang digunakan haruslah sesuai dengan tujuan pembelajaran; 2) media yang digunakan haruslah mendukung materi pembalajaran; 3) mudah diperoleh; 4) sesuai dengan keterampilan guru; 5) tersedia waktu untuk menggunakannya; dan 6) sesuai dengan taraf berfikir siswa.

Hasil penelitian yang dilakukan oleh Septi Dwi Putri et.al (2019) di Madrasah Ibtidaiyah Darussalam Kota Bengkulu menunjukkan hasil sebagian besar faktor problematika guru dalam menggunakan media kurikulum 2013 yaitu kendala yang dihadapi adalah berupa kesulitan dalam menentukan media pembelajaran yang sesuai dengan materi yang ada di dalam kurikulum. Dengan kata lain bahwa ada beberapa materi pembelajaran yang sulit untuk dicarikan dan dirangcang medianya. Hal ini sesuai dengan penelitian yang dilakukan oleh Ricky Pramita (2010) yang menyatakan bahwa guru mengalami problematika kurangnya keterampilan/kemampuan dalam membuat media pembelajaran selain itu sulitnya menselaraskan antara materi dengan media pembelajaran. Kesulitan Guru Dalam Menggunakan Media

Kendala kedua kesulitan guru dalam menggunakan media. Dalam pelaksanaan penggunaan media guru masih megalami kesulitan dimanan guru kelas 1 dan 3 mengaku tidak memiliki waktu yang cukup untuk membuat media pembelajaran, karena terlalu banyak media yang harus di buat dalam satu hari itu, sementara tugas guru di sekolah tidak hanya mengajar dan membuat bahan ajar seperti media namun melakukan kegiatan lainnya. Kemudia faktor dana dalam melengkapi fasilitas media pembelajaran kurikulum 2013 belum memadai. Guru kelas 2, 5 dan 6 mengaku dana dalam melengkapi fasilitas untuk keperluan membuat media serta fasilitas khusus media pada pembelajaran kurikulum 2013 belum di sediakan oleh sekolah. Hal tersebut menjadi problematika bagi guru dalam menggunakan media pembelajaran, dimana untuk membuat media guru harus mengeluarkan biaya sendiri.

Guru mengaku kesulitan dalam menerapkan media pembelajaran yang akan digunakan tersebut. terkait dengan guru mengaku tidak memiliki waktu yang cukup untuk membuat media pembelajaran, sementara tugas guru tidak hanya membuat media 
pembelajaran saja. Hal tersebut menjadi salah satu kendala yang dirasakan oleh guru kelas 1 dan 3. Di mana dalam kurikulum 2013 dalam setahun itu memiliki 8 tema. Semester satu berjumlah 4 tema dan semester dua ada 4 tema. Setiap tema, dibagi ke dalam 4 sub tema yang masing-masing sub tema terdiri dari 6 pembelajaran. Setiap pembelajaran memakan waktu 1 hari, dan setiap pembelajaran guru harus membuat media pembelajaran, karena banyaknya media yang harus dibuat oleh guru dalam satu hari menjadikan guru cukup kerepotan ketika harus mebuat media setiap hari.

Seperti yang di paparkan oleh Arum Mawar Kinasih (2017) dalam penelitiannya menyatakan bahwa salah satu problematika atau kesulitan yang di hadapi oleh guru ketika menyusun perangkat pembelajaran adalah keterbatasan waktu, sehingga guru tidak mampu menyusun perangkat pembelajaran secara optimal. Kendala guru tidak membuat media pembelajaran yaitu guru tidak memiliki banyak waktu untuk membuat media pembelajaran. Waktu guru sudah banyak tersita untuk mengajar di kelas, walaupun dirumah sudah memiliki pekerjaan lainnya. Hal tersebut yang menyebabkan jarang membuat media pembelajaran. Sebelum membuat perangkat pembelajaran guru biasanya menyusun Prota dan Prosem pada tiap awal tahun ajaran baru dimulai. Selain membuat media pembejaran, guru juga harus mengerjakan tugas lainnya. Tugas pokok dan fungsi guru sebagaimana tertera dalam UU No. 14 tahun 2005 tentang guru dan dosen pasal 35 ayat 1 bahwa beban kerja guru mencakup kegiatan pokok yaitu merencanakan pembelajaran, melaksanakan pembelajaran, menilai hasil pembelajaran, membimbing dan melatih peserta didik serta melaksanakan tugas tambahan. Penjabaran tugas pokok dan fungsi guru yang tertera dalam UU No. 14 tahun 2005 tentang guru dan dosen pasal 35 ayat 1 yaitu poin yaitu :

a. Membuat kelengkapan mengajar dengan baik dan lengkap (program mengajar dan bahan ajar)

b. Melaksanakan kegiatan pembelajaran

c. Melakukan kegiatan penilaian proses belajar, ulangan harian, ulangan umum dan ujian akhir.

d. Melaksanakan analisis hasil ulangan harian dan semester

e. Menyusun dan melaksanakan program perbaikan dan pengayaan

f. Mengisi daftar nilai anak didik

g. Membuat alat peraga

h. Mengikuti kegiatan pengembangan dan pemasyarakatan kurikulum

i. Melaksanakan tugas tertentu

j. Mengadakan pengembangan program pembelajaran.

k. Membuat catatan tentang hasil belajar anak didik

1. Mengisi dan meneliti daftar hadir sebelum memulai pembelajaran

m. Mengikuti semua kegiatan kedinasan

Banyaknya tugas yang harus dilaksanakan guru mengakibatkan waktu yang dimiliki oleh guru di sekolah harus digunakan efektif dan efisien. Menurut permendikbud Nomor 23 Tahun 2017 tentang hari Sekolah menjelaskan bahwa hari sekolah dilaksnakan 8 jam dalam sehari atau 40 jam dalam 5 hari kerja. Hari sekolah ini digunakan guru untuk melaksankan beban kerja guru. Berdasarkan penelitian yang dilakukan oleh Ricky Pramita (2010) kekurangan waktu dalam membuat media pembelajaran dapat di akibatkan karena 
banyaknya tugas yang harus dikerjakan oleh guru, sehingga waktu yang digunakan untuk membuat media pembelajaran tidak optimal hal tersebut mengakibatkan guru tidak membuat media pembelajaran ketika melaksanakan pembelajaran. Setelah jam sekolah guru tidak memiliki waktu luang karena harus mengurus keluarga dan pekerjaan lainnya diluar pekerjaan menjadi seorang guru.

Kemudian terkait dalam penggunaan dana dalam melengkapi fasilitas media pembelajaran belum memadai. Kendala ini menjadi salah satu pemicu problematika guru dalam menggunakan media pembelajaran. Dari hasil penelitian yang dilakukan oleh Suci Rahmiga (2019) setiap satuan pendidikan wajib memiliki sarana yang meliputi perabot, peralatan pendidikan, media pendidikan, buku dan sumber belajar lainnya, bahan habis pakai, serta perlengkapan lain yang diperlukan untuk menunjang proses pembelajaran yang teratur dan berkelanjutan. Ketersediaan fasilitas maupun dana untuk kebutuhan penggunaan media pembelajaran merupakan sarana dan prasarana yang dapat menunjang kelancaran proses belajar mengajar, dengan adanya fasilitas media pembelajaran yang memadai maka kelancaran dalam belajar akan dapat terwujud, dengan menyediakan fasilitas media pembelajaran yang lengkap, siswa akan lebih bersemanggat dalam belajar. Dengan adanya media media pembelajaran dapat mengatasi keterbatasan indera ruang dan waktu agar dalam proses belajar mengajar lebih memudahkan guru dalam menyampaikan materi.

\section{Kesulitan Guru dalam evaluasi penggunaan media pembelajaran}

Kendala ketiga Kesulitan dalam evaluasi penggunaan media pembelajaran. Berdasarkan data hasil wawancara diketahui seluruh informan mengaku banyak sekali kesulitan dalam melaksanakan penilaian yang disebabkan karena waktu yang terbatas. Dalam melakukan penilaian dikelas, guru-guru merasa terkendala dalam melakukan penilaian ketiga aspek yakni aspek sikap, pengetahuan, dan keterampilan karena guru harus mengajar, membimbing dan menilai tiga aspek dengan jumlah siswa yang cukup banyak dalam satu waktu. Guru merasa kesulitan karena waktu dalam satu pembelajaran tidak cukup untuk menilai siswa secara tuntas dengan berbagai macam aspek yang harus dinilai. Alokasi waktu untuk setiap pembelajaran hanya sehari. Padahal setiap satu pembelajaran terdapat tiga sampai empat kompetensi. Setiap kompetensi terbagi lagi menjadi beberapa indikator. Seringkali pada setiap pembelajaran, guru tidak dapat melakukan penilaian pada semua kompetensi secara tuntas. Hal ini membuat guru harus melanjutkan pada pertemuan berikutnya. Itu saja bisa dilanjutkan, jika masih ada waktu yang tersedia. Namun apabila tidak ada waktu, guru terpaksa langsung melanjutkan penilaian pada kompetensi dari pembelajaran berikutnya. Jadi tidak jarang guru tidak melaksanakan penilaian dikelas, tetapi dilakukan ketika jam istirahat atau dihari libur.

Waktu yang tersedia tidak mencukupi untuk melaksanakan penilaian autentik secara tuntas. Sesuai dengan hasil penelitian Purwandari (2014: 41) menemukan salah satu faktor yang menghambat guru dalam mengimplementasikan penilaian autentik, yaitu waktu yang terbatas. Adapun waktu yang terbatas menyebabkan guru kurang maksimal dalam menyusun perencanaan dan pelaksanaan penilaian autentik.

Hal ini dikarenakan alokasi waktu belajar yang tersedia tidak dapat menjangkau pelaksanaan penilaian terhadap seluruh kompetensi secara tuntas. Seringkali pada setiap 
pembelajaran, guru tidak dapat melakukan penilaian pada semua kompetensi yakni kompetensi sikap, pengetahuan dan keterampilan secara tuntas. Hal ini membuat guru harus melanjutkan pada pertemuan berikutnya. Karena guru harus melanjutkan penilaian pada kompetensi dari pembelajaran berikutnya.

Guru juga tidak memiliki waktu yang cukup untuk mempersiapkan semua instrumen penilaian. Terutama untuk instrument penilaian sikap dan keterampilan, guru sangat jarang melakukan penilaian tersebut karena banyak yang harus disiapkan dan memerlukan waktu yang banyak. Sedangkan dalam pelaksanaan penilaian didalam kelas, guru sangat jarang melaksanakan penilaian secara langsung karena guru hanya fokus mengajar siswa serta membimbing siswa sehingga guru melaksanakan penilaian ketika ada waktu luang. Sesuai dengan hasil analisis dokumen, 6 guru mengalami kesulitan dalam dalam menyelesaikan penilaian secara tuntas dikarenakan waktu yang terbatas. Hal tersebut dibuktikan melalui instrument penilaian yang tidak terisi lengkap, masih terdapat instrument yang kosong, bahkan terdapat guru yang tidak menyiapkan instrument penilaian. Kemudian rekapan nilai siswa juga masih belum terisi, hal itu membuktikan bahwa guru belum sempat melakukan penilaian secara tuntas karena waktu yang terbatas.

Berdasarkan teknik uji keabsahan yang digunakan pada aspek ini yakni perbandingan antara data hasil wawancara dengan data dokumentasi, maka dapat diketahui bahwa data hasil wawancara sudah sesuai dengan data hasil analisis dokumentasi. Jadi berdasarkan hasil analisis tersebut, dapat diketahui bahwa semua guru kesulitan dalam melaksanakan proses perencanaan penggunaan media pembelajaran dengan ketersediaan waktu yang terbatas. Semestinya guru sebagai pendidik yang profesional harus mampu untuk mengatur waktu sebaik mungkin dengan cara membuat perencanaan waktu terlebih dahulu agar semua proses kebutuhan pembelajaran dapat terlaksana secara tuntas dan tidak terburu-buru, kemudian sebelum melaksanakan penilaian baiknya guru membuat prosedur penilaian yang terencana sehingga pelaksanaan penilaian dapat dituntaskan.

Berdasarkan hasil analisis data diketahui bahwa solusi yang pernah dicoba guru dalam mengatasi kendala dalam menggunakan media masih cukup rendah. Hal ini terbukti dari guru belum mampu mengatasi hambatan-hambatan pada pelaksanaan penggunaan media pembelajaran. Sesuai dengan hasil penelitian Rubini et al (2018) \& Hartati et al (2021). Hasil penelitian menunjukkan bahwa: 1) problematika guru terdiri dari problem internal, meliputi: (a) kompetensi pedagogis, yaitu lemahnya menguasai kelas, miskin inovasi dan kreativitas, minat baca rendah, kurang menguasai teknik penilaian yang baik dan guru kurang bahkan tidak menguasai media pembelajaran yang berbasis teknologi informasi, (b) kompetensi profesional, yaitu kurang menguasai materi, (c) kelayakan kompetensi, yaitu sikap kurang mencintai pada profesi. Sedangkan problem eksternal, meliputi: besarnya kelas, suasana belajar, fasilitas dan sumber belajar yang terbatas. sehingga pelaksanaan proses pemanfaatan penggunaan media terhambat.

Adapun solusi yang pernah dilakukan guru untuk mengatasi kesulitan dalam melaksanakan penggunaan media pembelajaran yakni guru mengaku biasanya menggunakan buku siswa sebagai alternatif ketika guru mengalami kesulitan dalam memilih media pembelajaran yang akan digunakan. Kemudian guru ketika mengalami keterbatasan sarana dan prasarana guru memanfaatkan media sederhana seperti buku siswa, media gambar dan lingkungan sekitar sebagai sumber belajar. Dan ketika guru 
mengalami kendala dalam mengevaluasi media rata-rata guru melakukan penilaian dilain waktu, sepeti ketika jam istirahat, hari libur, waktu senggang.

Mestinya guru lebih aktif lagi untuk mengatasi hambatan-hambatan yang dialami dalam pelaksanaan penggunaan media pembelajaran. Jadi tidak hanya melalui menggunakan buku siswa sebagai alternative ketika menghadapi kendala tetapi guru juga harus memiliki inisiatif sendiri untuk mengatasi hambatan dengan cara mencari refrensi lain terkait kesulitan yang dialami melalui buku, internet, buku ilmiah, buku panduan, majalah, berita, kemudian guru harus aktif juga dalam mencari pelatihan /worksop yang dilakukan secara daring yang dapat diakses kapan saja dan dimana saja. Pemanfaatan media pembelajaran merupakan amanat kurikulum 2013, dimana pembelajaran dilaksanakan berbasis aneka sumber belajar. guru tidak lagi menjadi satu-satunya sumber belajar. disamping itu, berdasarkan prinsip pembelajaran kurikulum 2013 pemanfaatan media dapat meningkatkan efisien dan efektivitas pembelajaran. oleh karena itu, penting sekali bagi guru menggunakan media pembelajaran mulai dari tahap perencanaan, pelaksanaan dan penilaian hasil belajar.

\section{PENUTUP}

\section{Simpulan}

Berdasarkan penelitian terkait Problematika Guru dalam Menggunakan Media Pembelajaran Kurikulum 2013 di Negeri 1 Taman Ayu Dusun Peseng Desa Taman Ayu, Gerung, Kabupaten Lombok Barat diperoleh kesimpulan sebagai berikut:

Bentuk - bentuk kesulitan guru dalam melaksanakan penggunaan media pembelajaran: (1) Kesulitan dalam perencanaan media pembelajaran, kendala yang dihadapi adalah berupa kesulitan dalam menentukan media pembelajaran yang sesuai dengan materi yang ada di dalam kurikulum. Dengan kata lain bahwa ada beberapa materi pembelajaran yang sulit untuk dicarikan dan dirancang medianya. Hal ini menjadikan guru cukup kesulitan dalam menyesuaikan media dengan materi pembelajaran; (2) Kesulitan dalam menggunakan media pembelajaran, Sarana dan prasarana yang kurang dan keterbatasan waktu untuk membuat media juga merupakan salah satu faktor kesulitan guru dalam menggunakan media pembelajaran; (3) Kesulitan dalam evaluasi penggunaan media pembelajaran, Jumlah siswa yang terlalu menyulitkan guru dalam melaksanakan penilaian, guru merasa cukup kualahan dan memerlukan energi serta waktu yang banyak jika penilaian tersebut dilakukan dalam satu waktu. Guru merasa kesulitan juga melakukan penilaian karena selaian menilai guru juga harus fokus untuk membimbing siswa secara intens, mengajar dan mengawasi siswa mengingat kelas rendah dikenal dengan siswanya yang masih sangat aktif.

Strategi guru dalam mengatasi kendala dalam menggunakan media' (1) Pertama guru memanfaatkan buku siswa sebagai alternative media yang digunakan ketika menghadapi kendala; (2) Guru menggunakan media sederhana seperti media gambar dan memanfaatkan lingkungan sekitar sebagai sumber media pembelajaran strategi ini dirasa guru dapat mengatasi keterbatasan sarana dan prasaran; (3) ketika guru tidak dapat melakukan mengevaluasi penilaian secara langsung guru biasanya melakukan penilaian dilain waktu, sepeti ketika jam istirahat, hari libur, waktu senggang. 


\section{Saran}

Berdasarkan hasil penelitian, peneliti dapat memberikan saran terkait permasalahanpermasalahan yang dihadapi oleh guru dalam menggunakan media pembelajaran kurikulum 2013:

1. Guru harus lebih aktif dalam mencari informasi terkait penggunaan media pembelajaran pada kurikulum 2013, tidak hanya mengandalkan pelatihan/workshop yang diberikan oleh pemerintah.

2. Pihak sekolah diharapkan mendukung secara optimal dalam penyediaan dan penggunaan media pembelajaran dalam proses belajar mengajar, sekolah harus meningkatkan lagi kuantitas dan kualitas media pembelajaran yang ada disekolah.

3. Kepala sekolah hendaknya selalu melakukan pembinaan dalam meningkatkan kualitas PBM yang dilakukan oleh guru-guru mulai dari penyusunan perangkat pembelajaran, pengelolaan kelas, penggunaan media, evaluasi, menyusun rencana pengembangan sekolah, melakukan pengawasan dan evaluasi.

\section{DAFTAR PUSTAKA}

Arsyad, Azhar. (2014.) Media Pembelajaran. Jakarta: RajaGrafindo Persada.

Departemen Pendidikan Nasional. (2005). Undang-Undang Nomor 14 Tahun 2005. Tentang Guru Dan Dosen, Jakarta: Depdiknas.

Departemen Pendidikan Nasional. (2005). Undang-Undang Nomor 23 Tahun 2007. Tentang Hari Sekolah, Jakarta: Depdiknas.

Hartati, Y., Ilhamdi, M. L., \& Khair, B. N. (2021). Proses Penggunaan Media Pembelajaran Montessori Pada Materi Penjumlahan Dan Pengurangan Untuk Siswa Kelas 1 SD. JURNAL ILMIAH PENDAS: PRIMARY EDUCATION JOURNAL, 2(1), 67 - 71. https://doi.org/10.29303/pendas.v2i1.103

Kinasih, A. M., \& Risminawati, M. P. (2017). Problematika Guru Dalam Penyusunan Perangkat Pembelajaran Di SD Muhammadiyah 14 Surakarta (Doctoral dissertation, Universitas Muhammadiyah Surakarta).

Kustandi, dan Sutjipto. (2011). Media Pembelajaran Manual dan Digital. Jakarta: Ghalia Indonesia.

Lutfi, Sudirman, Pramitha. (2013). Sisi Lain Kebijakan Profesionalisme Guru: Optik Hukum, Implementasi dan Rekonsepsi. Malang: Universitas Brawijaya Press (UB Press).

Milles, B. Mathew B. \& Huberman. M. (1992). Analisis data kualitatif. Jakarta: UI-Press

Moleong, Lexy. (2000). Metodologi Penelitian kualitatif. Bandung: Remaja Rosdakarya.

Pramita, Ricky. (2010). Problematika Guru dalam Membuat Media Pembelajaran (Studi kasus SMA Negeri di kota Malang):32-33

Purwandari, Apriliana. (2014). Penilaian Autentik pada Mata Pelajaran Matematika Kurikulum 2013 Guru kelas IV Kota Semarang. Jurnal Pendidikan Matematika, 4 (2), 41

Rahmiga, Suci. (2019). Kurangnya Sarana Dan Prasarana Belajar Di Sekolah. INA-Rxiv, December, 6. 
Rubini, B., Permanasari, A., \& Yuningsih, W. (2018). Learning multimedia based on science literacy on the lightning theme. Jurnal Penelitian dan Pembelajaran IPA, 4(2), 89-104.

Sadiman, Rahardjo dan Haryono. (2014). Media pendidikan : pengertian, pengembangan dan pemanfaatannya. Depok: PT. Raja Grafindo Persada.

Septi D, Desy E. (2019). Problematika Guru Dalam Menggunakan Media Pembelajaran Pada Mata Pelajaran Ips Di Madrasah Ibtidaiyah Darussalam Kota Bengkulu.

Sudjana, N. dan Rivai, A. (2015). Media Pengajaran. Bandung: Penerbit Sinar Baru

Sukardi. (2011). Metodologi Penelitian Pendidikan Kompetensi dan Praktiknya. Yogyakarta: Bumi Aksara.

Sumantri, P. (1999). Strategi Belajar Mengajar . Jakarta: Depdibud

Tohirin. (2012). Metode Penelitian Kualitatif Dalam Pendidikan Dan Bimbingan Konseling. Jakarta: PT Rajagrafindo Persada

Untari, Esti. (2017). Problematika Guru dan Pemanfaatan Media Pembelajaran Sekolah Dasar di Kota Blitar.Jurnal Penelitian Pendidikan Dasar.

Wulantari, V., Ermiana, I., \& Oktaviyanti, I. (2021). Analisis Kesulitan Guru Dalam Pembuatan Rencana Pelaksanaan Pembelajaran Kurikulum 2013 Gugus 1 Kecamatan Gerung. JURNAL ILMIAH PENDAS: PRIMARY EDUCATION JOURNAL, 2(1), 72 81. https://doi.org/10.29303/pendas.v2i1.104 